Ph.D. Bojan S. Dimitrijević ${ }^{1}$, Full Professor

Belgrade Business School, Kraljice Marije 73, 11000 Belgrade, Serbia

Ph.D. Vladimir Đ. Đaković ${ }^{2}$, Assistant Professor

University of Novi Sad, Faculty of Technical Sciences, Novi Sad, Serbia

Ph.D. Goran B. Anđelić3 , Associate Professor

Educons University, Faculty of Business Economy, Sremska Kamenica,

Serbia

M.Sc. Nataša S. Glišović ${ }^{4}$, Teaching Assistant

State University of Novi Pazar, Department of Mathematical Sciences, Novi Pazar, Serbia

\title{
SUNSPOTS AND STOCK MARKETS: SOME EMPIRICAL EVIDENCE OF THEIR INTERDEPENDENCE IN \\ TRANSITION COUNTRIES*
}

ABSTRACT: Econophysics is a new and growing discipline that strives to connect and establish the interdependence between natural phenomena and human economic activities. A growing number of studies attempts to prove empirical correlation and cause-effect interdependence between sunspots and the behaviour of stock market indices. This relationship is theoretically based on the fact that sunspots cause enhanced geomagnetic activity of the Earth, and it changes human psychology and behaviour, inducing waves of

* The authors acknowledge the financial support of the Ministry of Education, Science and Technological Development of the Republic of Serbia, within the Projects No. III47028 and No. III44006.
} 
optimism and pessimism, which affect investment intensity in stock markets, stock prices and return size. Therefore, the article explores the empirical correlation between sunspot activity and behaviour of stock indices in four growing stock markets in former transition countries (Hungary, Slovenia, Croatia and Serbia). The period of seven years (2005 to 2012) is analyzed since it coincides with the outbreak of the global economic crisis (late 2008). The research results indicate that there exist empirical correlation and causality, in accordance with theoretical expectations.

Keywords: Sunspots, Stock markets, Transition countries, Correlation, Cointegration.

\section{INTRODUCTION}

Analyses of the conditions and opportunities in the stock markets are the focus of researchers for many years. Decision making on investing activities in stock markets is directly related to possibilities of risk prediction that accompany these activities. In this sense, the researchers have analyzed stock markets from different perspectives, but common to all these studies is the effort to anticipate business changes and circumstances in stock markets, in order to make business decisions and create investment strategies directed towards minimization of investment risks.

Various methods have been developed in order to manage the investment risk in the stock markets, with more or less success. Ex-ante analysis of stock market conditions is common to all of them, in order to anticipate circumstances that lead to certain trends and developments. The consequences of these efforts are, among others, different approaches towards stock market analysis and certain phenomena interdependence testing, even if it seems there is no apparent correlation between them. A special approach to analysis of relationships, influences and connections between certain parameters to create the business climate in stock markets is the one that tries to connect and establish the interdependence between natural phenomena and human economic activities. It has been unequivocally confirmed, both in theory and in studies, that there exist interdependencies between human behaviour and certain physical phenomena. Econophysics as a new and fast growing scientific discipline focused on testing, analysis and implementation of specific information about connection and interdependence of economic and physical phenomena.

Based on such premises, the subject of this study is to test and analyze the empirical interdependence between sunspot activity and the behaviour of stock indices in four growing stock markets of the former transition countries (Hungary, Slovenia, Croatia, Serbia), in the period 2005 2012. Sunspots typically appear as a relatively small, dark and pore-like feature on the surface or 'photosphere' of the sun (Johnson, 2011). Stock market indices are used in the study as indicators of status, conditions and opportunities in observed stock markets because of their reliability and descriptiveness (comprehensiveness) and because they represent the official stock exchange information. The research is focused on high propulsive, relatively low liquidity and "shallow" stock markets of South Eastern Europe, with similar evolutionary paths, but in different stages of transition (Hungary and Slovenia as EU members in the first wave of accession, Croatia as a new member of the EU and Serbia as the EU candidate). The research covers the time period 2005 - 2012, with the ambition to analyze and test the interdependence between sunspot activities and the behaviour of stock indices, both before the global economic crisis and in the period after its outbreak, in order to make certain conclusions about the interdependencies in various market conditions (positive conjunction; recession), compare the results and set them analytically.

The main objective of this research is to demonstrate that sunspot activity and behaviour of stock indices correlate in the observed transitional markets. The confirmed correlation may become a basis for better anticipation of future price movements and returns in the stock markets. In this sense, the study has both academic and practical significance. Academically, it will provide high quality information, verified in practice, about the interdependence between sunspot activity and stock market indices behaviour, which will create a real space for further research in this field. Practically, it will provide a reasonable basis for business decision-making for investors and economic policymakers, based on knowledge of the expected variations of sunspot activity and their consequences in the stock indices. The special significance of the research is reflected in the fact that, to our knowledge, there are no comparative empirical studies focused on the stock markets of transition economies, so the study results will considerably expand the cognitive basis of this new and dynamic scientific area.

The following hypotheses are tested in the study:

Hypothesis 1

$\mathrm{H}_{0}$ : There is a statistically significant negative correlation between stock indices in the observed four stock markets and the sunspot activities in the period 2005-2012, measured by their number.

$\mathrm{H}_{1}$ : There is no statistically significant negative correlation between stock indices in the observed four stock markets and the sunspot activities in the period 2005-2012, measured by their number. 
Hypothesis 2 series.

$\mathrm{H}_{0}$ : Time series of stock indices are cointegrated with sunspot time

$\mathrm{H}_{1}$ : Time series of stock indices are not cointegrated with sunspot time series.

Hypothesis 3

$\mathrm{H}_{0}$ : Stock index series are non stationary, they have a unit root and they are random walk.

$\mathrm{H}_{1}$ : Stock index series are stationary, they do not have a unit root and they are not random walk.

Hypothesis 4

$\mathrm{H}_{0}$ : Stock market index series are different from normal distribution.

$\mathrm{H}_{1}$ : Stock market index series are not different from normal distribution.

The study is structured as follows: the subject of the research, its objectives and hypotheses, as well as its importance, are presented in the introductory part; the second part consists of the basic theoretical explanation and review of relevant literature in the field; and the third part presents the methodology applied in the research. Next, the fourth part comprises the data and research results, while the fifth part includes the resulting conclusions related to the tested hypotheses. The references used in the research are placed in the end of the study.

\section{THEORETICAL BACKGROUND}

The realized research has its practical and academic dimensions. In this sense, it is significant because it offers high-quality, field-tested practical information on relevant aspects of the interdependence between sunspot activities and behaviour of stock indices in specific transitional markets. Monitoring the sunspot behaviour in the context of time, based on the analysis of the realized studies in the field, shows an 11-year sunspot cycle. This fact is important especially because stock market changes also occur cyclically, i.e. in particular "waves" of conjuncture. It has been confirmed that the change in number of sunspots cause changes in geomagnetic activities and the joint interaction of these two variables influence human behaviour in terms of decision making (waves of optimism and pessimism). In the end, all this is reflected in the willingness to invest and cycles of economic conjuncture. In this sense, the sequence of causation is normally distributed as follows: increased solar activity (sunspot number growth) leads to enhanced geomagnetic activity (geomagnetic storms). The increased geomagnetic activity causes hormonal and psychological changes in human behaviour (mainly related to the secretion of the hormone melatonin), which affects depressive behaviour. Waves of pessimism caused by depression deter people from investing and business decisions related to expansion of business activities. Therefore, there is a theoretically expected result that there is a negative correlation between the sunspot number increase and fluctuation of index prices and the level of return in stock exchanges.

It is particularly interesting to test and analyze the circumstances and interdependences in transitional stock markets, which are in many aspects specific and different if compared with developed markets. Comparative analysis of referential studies shows that there is a negative correlation between changes in sunspot number and changes in market indices, which creates a scientific basis for further research on this topic.

Many authors have studied the interdependence between sunspot activity and market behaviour. Some of the most representative studies are used for the purpose of this research and a few will be presented here. It is necessary to point out the fact that stock index series are non stationary variables, they have a unit root, and so they are random walks. These facts are very important because a shock has a permanent effect on the time series level with a unit root, for an indefinite period of time, in the sense that the time series deviation from a long-term trend is not occasional, but constant for an indefinite period of time (Mladenovic, 2008). Consequently, it is necessary to transform non-stationary (random walk) series to stationary ones using an appropriate statistical procedure. This is important for this research, because the sample covers the period before and after the outbreak of the global economic crisis. Based on these cognitions, it is possible to describe the specific circumstances and trends in the behaviour of the time series tested in the research. In their study, Dimitrijevic et al. (2013) try to respond to the question if there were scientists who predicted the economic crisis. The answer is that those were the physicists using various physical models. Modern trends in this area indicate the need for mathematical exactness and quantitative predictability of economic trends, and appropriate use of corresponding statistical and mathematical methods in order to improve the predictability of monitored market indicators. The authors suggest that economic cycles and time series oscillations (stationary, trend stationary, random walk, cointegrated) fit other theoretical models and methods of modern physics, and that there exist more and more studies claiming that economic cycles decisively depend on the solar electromagnetic activity and cycles, known as sunspots.

Jovanovic et al. (2013) indicate a new approach in modern financial theory directed to the growing scientific discipline that tries to articulate and establish interdependences between natural phenomena and human economic 
activities. The authors also imply the need of "new players" 5 in modern financial theory. Particularly noteworthy is the need to develop econophysics in investments, i.e. adequately analyze and create economic impacts on the course and effectiveness of investments, with specific emphasis on monitoring of extreme events increase and consequent market volatility. In this research, the authors both theoretically and practically indicate the place, role and importance that econophysics should have in modern financial theory, paving the way for a large number of studies in this area. In his article, Collins (1965) examines the effect of sunspots on the stock market, identifies a number of practical examples and the correlation between the two phenomena. Among other things, the author quotes Herschel, who finds a correlation between sunspot activity and natural phenomena on Earth in 1801. One of the first authors observing correlation between sunspot activities and business cycles is a famous English economist and one of the greatest minds of his time, W. Stanley Jevons, also known as the creator of the marginalist revolution in economic theory. Garcia-Mata and Schaffner imply the relationship between solar activity and industrial production, which makes a significant step in the study of the subject area. Smith points out the link between sunspots and human psychology, creating a realistic basis for testing the interdependence in specific cases.

Modis (2007) investigates the correlation between sunspots, the GDP and the stock market in the sample covering the period of 80 years. The obtained correlation is not statistically significant, but there is an unquestionable visually observed correlation between time series, which leads to the impression that the quantitative and maybe causal relation actually exists. The time lag between the observed phenomena is also indicated. This research is particularly important because it emphasizes objectivity, adaptability and flexibility of science-based tools in the decision making process, especially when human psychology is accented as the dominant factor in investment decisions, which is not uncommon in the stock markets and in business decision-making.

Hirshleifer et al. (2003) analyze the correlation between the morning sunshine in the city and returns of the leading stock indices in 26 countries. The authors conclude that investors can achieve higher returns from investing activities, especially if they avoid mood-based errors in their judgments and trades. In order to adequately analyze changes in the market asset pricing, it is necessary to identify factors that affect investors' moods and emotions, with a special emphasis on the weather effects.

\footnotetext{
5 The authors are aware of the fact that financial economy and financial mathematics dominate modern financial theory, but also indicate that econophysics takes an increasing share in the process of redesigning the theoretical assumptions of modern economic theory.
}

Hampson (2011) points to the importance of analyzing sunspot activity and financial markets. In his article, the author empirically tests and finds a correlation between rising solar activity and periods of inflationary trends. Maximum and minimum solar activities correlate with maximum and minimum stock prices in the reporting period. Each solar maximum is followed by a recession, corresponding to the peaks in geomagnetism (theoretically expected negative correlation). The study indicates the importance and need for further monitoring of solar activity and movement predictions in the financial markets, in the context of optimal investment decision-making.

Krivelyova et al. (2003) test the impact of geomagnetic storms on daily stock market returns, i.e. they explore the effects of geomagnetic storms on human behaviour (health), judgment and investment risk perception. They undoubtedly determine the influence of geomagnetic storms on human mood changes and pessimistic attitudes about stock market movements, which increases demand for risk-free assets and consequently reduces market prices of risky assets. They conclude that high levels of geomagnetic activity have a negative impact on returns of US stock indices and that further empirical testing in this area is needed, especially on controlling of cross-country differences.

Kamstra et al. (2003) investigate the impact of seasonal climate changes on seasonal fluctuations of stock market returns around the world. The importance of depression is emphasized as a cause of increased risk aversion. The influence of a seasonal disorder of time is more evident if the conditions and opportunities in the stock markets of both Southern and Northern Hemisphere countries are analyzed. The authors conclude that there is an effect of seasonal affective disorder of time (the Southern Hemisphere is six months behind the Northern Hemisphere), and it is necessary to analyze further the behavioural framework when explaining the return on investment activities in the analyzed markets.

The aforementioned theoretical and empirical studies show the actuality of the research area, especially if transitional markets lacking such research are considered. It is evident that psychological factors as a result of meteorological characteristics have an important place and role in the analysis and optimal investment decision-making, in terms of expected returns with appropriate risk assessment.

\section{METHODOLOGY AND DATA ANALYSIS}

In the research, the data (daily values of BELEX15, BUX, CROBEX, SBITOP stock indices and SUNSPOTS daily values) are tested on a sample 
period from October 4, 2005 to December 27, 2012. BELEX15 represents 15 most liquid stocks at the Belgrade Stock Exchange (Serbia), BUX is the official index of blue-chip stocks listed on the Budapest Stock Exchange (Hungary), CROBEX is an exchange index at Zagreb Stock Exchange (Croatia) and SBITOP is the blue-chip index of the most liquid and highly capitalized stocks at the Ljubljana Stock Exchange (Slovenia).

The sample consists of 1185 observations, without zero sunspots, and 1700 observations, with zero sunspots included. The data related to the number of sunspots are taken from the USA National Geophysical Data Center website (http://www.ngdc.noaa.gov/stp/solar/ssndata.html), and the stock indices are taken from the official Exchange Internet websites of the observed countries.

In the research, a trial correlation between sunspots and the indices are conducted in four ways:

1) The data are tested as they are right;

2) The data are tested when sunspots are different from zero, i.e. when there exist changes,

3) Data and calculated correlations are logarithmed; Several benefits of using logarithmed, both theoretic and algorithmic (Hudson, 2010; Meucci, 2010).

4) Data returns and correlations are calculated.

These results are presented in tabular forms. Generally, taking into account the results, the best correlations are obtained when considering 2), i.e. when the days with sunspot changes are tested.

When the correlation of the obtained data is taken into account and examined the significance of the data changes when turned to zero and when they are excluded, further analysis are performed on the data without zero.

At the beginning of the analysis, the distribution of the sample is tested with the Kolmogorov-Smirnov test (Table 1), in order to determine whether the sample has normal distribution. On the basis of the central dispersive parameters, the picture of the sample distribution is gained. ${ }^{6}$ Table 1 shows the normal distribution results.

\footnotetext{
${ }^{6}$ The normal distribution of sample means that the coincidental variable (x), with the arithmetical middle $\mu$ and the standard deviation $\sigma$ is normally distributed in case the function of probability $f(x)$ gives the variable $(x)$ the value of $X$.
}

Table 1. - Kolmogorov - Smirnov normality test for the stock indices and sunspots in the period October 4, 2005 - December 27, 2012

\begin{tabular}{|l|r|r|}
\hline $\begin{array}{l}\text { Kolmogorov- } \\
\text { Smirnov test }\end{array}$ & Statistic & \multicolumn{1}{|c|}{ Sig. } \\
\hline BELEX15 & 0.243 & 0.000 \\
\hline BUX & 0.096 & 0.000 \\
\hline CROBEX & 0.258 & 0.000 \\
\hline SBITOP & 0.191 & 0.000 \\
\hline SUNSPOTS & 0.170 & 0.000 \\
\hline
\end{tabular}

Kolmogorov-Smirnov test of distribution normality shows that stock indices and sunspots do not have a normal distribution and that in future research it is necessary to use tests that examine different distribution. Please note that these results are consistent with the conclusions of econophysicists who identify Pareto and Levy distributions and other statistical distributions (Jovanovic et al, 2013).

Further tests examine the data consistency or data loss, so their characteristics (mean, number, standard deviation, minimum and maximum, range) are tested. Namely, when working with large amounts of data, accidental data corruption or data loss can happen caused by the creation of a valid database. Consequently, the characteristics that should satisfy the data (number, minimum, maximum, etc.) are analyzed. Therefore, descriptive analysis of the research sample is performed (Table 2).

Table 2. - Descriptive statistics summary for stock indices and sunspots

\begin{tabular}{|l|r|r|r|r|r|r|}
\hline Name & \multicolumn{1}{|c|}{ Mean } & \multicolumn{1}{c|}{$\mathrm{N}$} & \multicolumn{1}{c|}{ Std. Deviation } & \multicolumn{1}{c|}{ Minimum } & \multicolumn{1}{c|}{ Maximum } & \multicolumn{1}{c|}{ Range } \\
\hline BELEX15 & 987.5575 & 1185 & 662.05093 & 386.44 & 3304.64 & 2918.20 \\
\hline BUX & 21044.4115 & 1185 & 3260.10138 & 9880.37 & 30005.10 & 20124.73 \\
\hline CROBEX & 2433.4876 & 1185 & 917.69833 & 1283.45 & 5279.14 & 3995.69 \\
\hline SBITOP & 1029.0057 & 1185 & 501.46414 & 501.27 & 2674.69 & 2173.42 \\
\hline SUNSPOTS & 33.0118 & 1185 & 27.40814 & 7.00 & 136.00 & 136.00 \\
\hline
\end{tabular}

Source - the authors' calculations

In the further research, the type of time series is examined, if it is stationary or non stationary and whether it has a unit root. The Dickey Fuller (DF) Unit Root Test is used to investigate whether time series are stationary or have a unit root. Based on the test results obtained by the time series of stock market indices, they are non stationary, i.e. they have a unit root, while 
sunspots are stationary time series.

The early and pioneering work on testing a unit root in time series is done by Dickey and Fuller (Dickey and Fuller 1979; Fuller 1976). The basic objective of the test is to test the null hypothesis that $\varphi=1$ in:

$\mathrm{yt}=\varphi \mathrm{yt}-1+\mathrm{ut}$

against the one-sided alternative $\varphi<1$.

A unit root is present if $\varphi=1$. The model is non-stationary in this case.

Critical values are derived from Monte Carlo experiments by Fuller (1976), for example. Relevant examples of the distribution are shown in Table 3 below.

Table 3. - Critical Values for DF and ADF Tests

\begin{tabular}{|l|l|l|l|}
\hline $\begin{array}{l}\text { Significance } \\
\text { level }\end{array}$ & $10 \%$ & $5 \%$ & $1 \%$ \\
\hline $\begin{array}{l}\text { C.V. for a } \\
\text { constant } \\
\text { without trend }\end{array}$ & -2.57 & -2.86 & -3.43 \\
\hline $\begin{array}{l}\text { C.V. for a } \\
\text { constant with } \\
\text { trend }\end{array}$ & -3.12 & -3.41 & -3.96 \\
\hline
\end{tabular}

Source-Fuller (1976)

The null hypothesis of a unit root is rejected in favour of the stationary alternative in each case if the test statistic is more negative than the critical value. Test values are given in Table 4.

Table 4. - Dickey-Fuller test values for the stock indices and sunspots

\begin{tabular}{|l|r|r|r|}
\hline Name & DF & Lag order & p-value \\
\hline BELEX15 & -2.02 & 10 & 0.57 \\
\hline BUX & -3.04 & 10 & 0.14 \\
\hline CROBEX & -2.25 & 10 & 0.47 \\
\hline SBITOP & -1.98 & 10 & 0.59 \\
\hline SUNSPOTS & -4.16 & 10 & 0.01 \\
\hline \multicolumn{4}{|c}{ Source - the authors' calculations }
\end{tabular}

The performed analysis of stationary time series shows that BELEX15, BUX, CROBEX, SBITOP (with trend) are non-stationary time series, but SUNSPOTS (with the magnetic helicity $(\mathrm{HmH})$ ) is stationary (Table 4). These results are also consistent with theoretical expectations and previous findings obtained by numerous authors of econophysics about the nature and behaviour of the time series of stock market indices in the financial markets (Jovanovic et al, 2013).

Because of the results of the DF test, there is a need to do the firstdifference tests of the stock indices and sunspots (Table 5) and thus find a model to transform non-stationary series into stationary ones.

This is important, because dependence assessment, which is the focus of the research of non-stationary time series, produces false image of high correlation and it causes arbitrary regression. The results obtained in this way are biased and inconsistent. This problem can be overcome by transforming the values to stationary ones and by estimating first-differences. The assessments of long-term equilibrium relationships, reflecting the systemic relations in economy, are thus enabled and the analysis is very important for the quality of the obtained conclusions.

Table 5. - DF test results when testing the first differences

\begin{tabular}{|l|r|r|r|}
\hline Name & DF & Lag order & p-value \\
\hline BELEX15 & -7.99 & 10 & 0.01 \\
\hline BUX & -10.19 & 10 & 0.01 \\
\hline CROBEX & -7.38 & 10 & 0.01 \\
\hline SBITOP & -7.39 & 10 & 0.01 \\
\hline SUNSPOTS & -4.16 & 10 & 0.01 \\
\hline
\end{tabular}

ARIMA-models for each stock index and sunspots are obtained by transition from stationary to non-stationary time series. Multiple tests of stationarity are examined for sunspots and thus more ARIMA-models are gained (see Fig. 1.1, 2.1, 3.1, 4.1, and 5.1)

Figure 1. - BELEX15 non-stationary time series

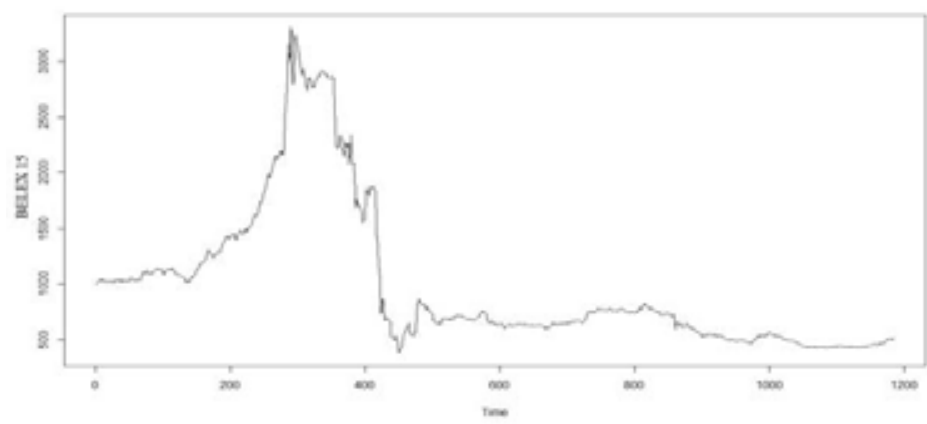

Source - the authors' calculations 
Figure 1.1. - BELEX15 stationary time series after transformation (ARIMA time series $(4,1,5)$ of BELEX15)

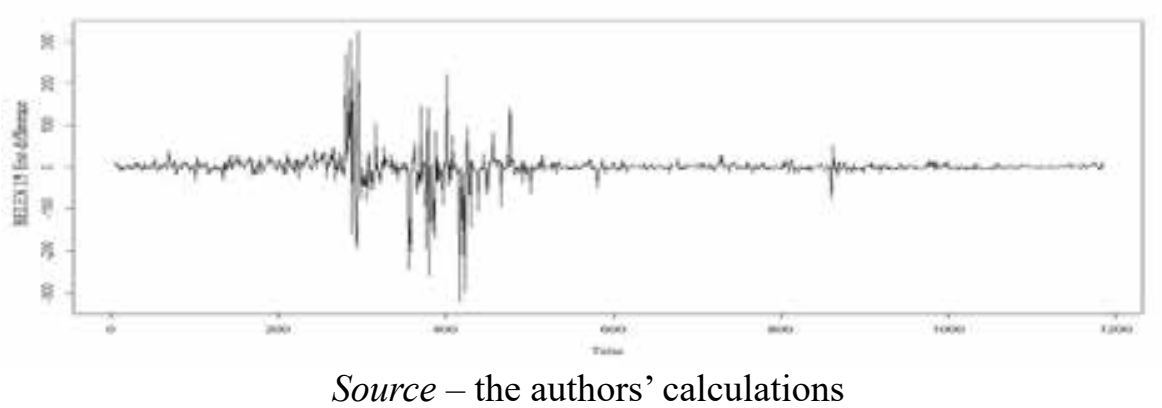

Figure 2. - BUX non-stationary time series

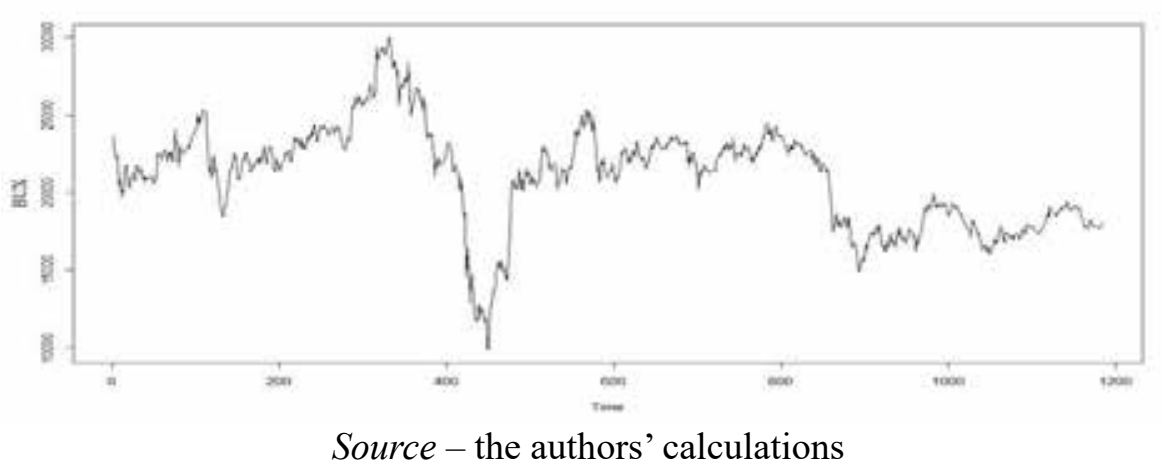

Figure 2.1. - BUX stationary time series (ARIMA time series $(1,1,1)$ of BUX)

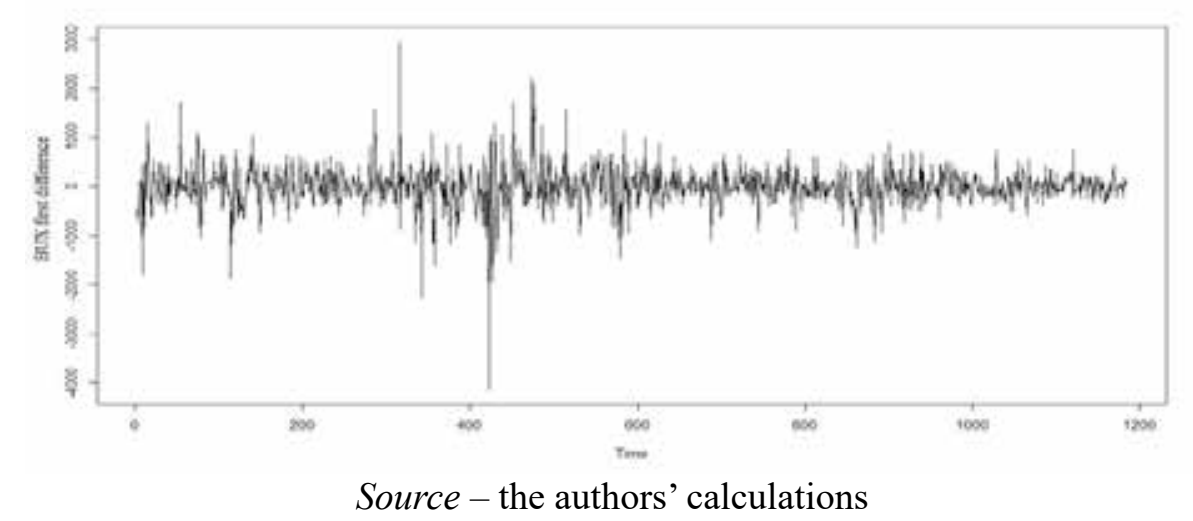

Figure 3. - CROBEX non-stationary time series

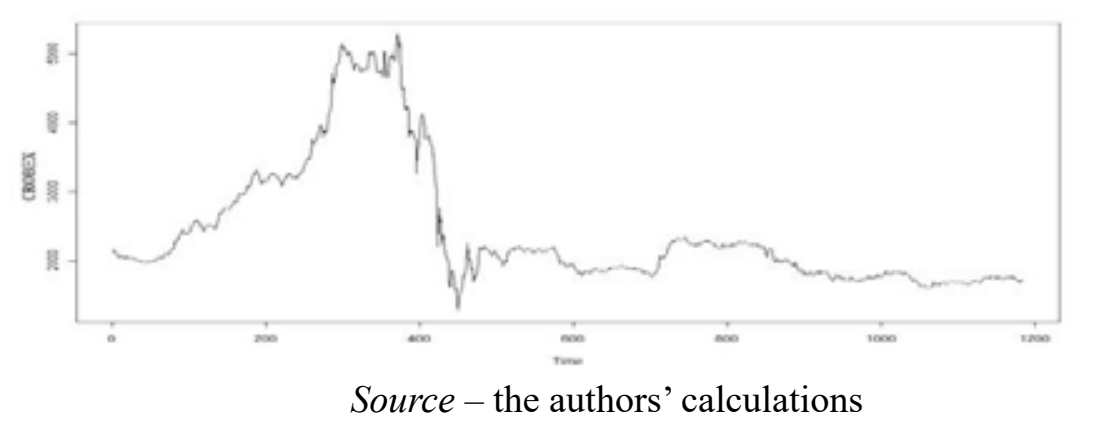

Figure 3.1. - CROBEX stationary time series (ARIMA time series $(3,1,3)$ of CROBEX)

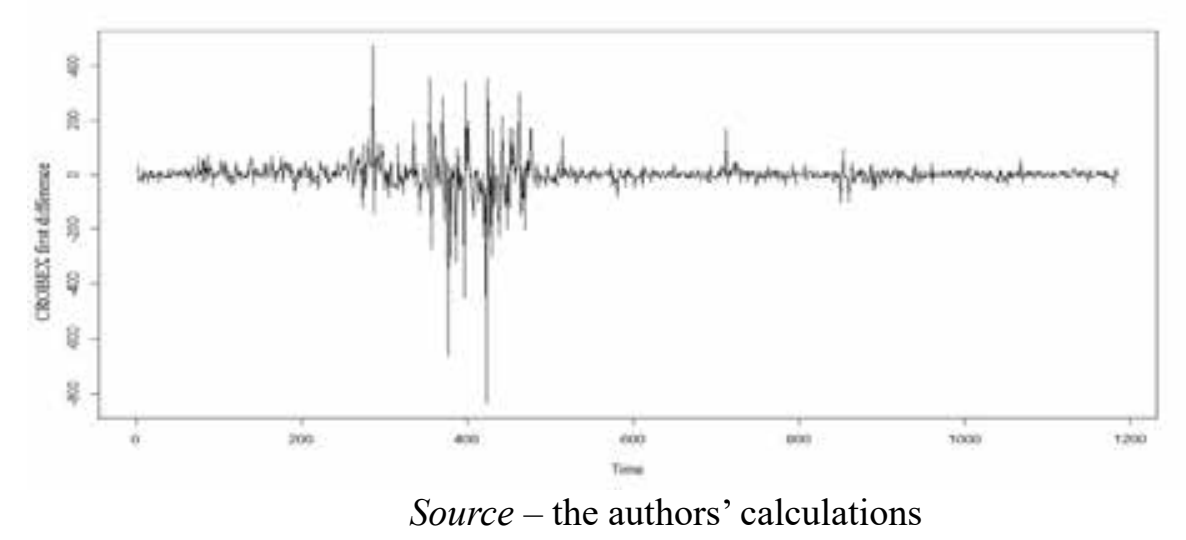

Figure 4. - SBITOP non-stationary time series

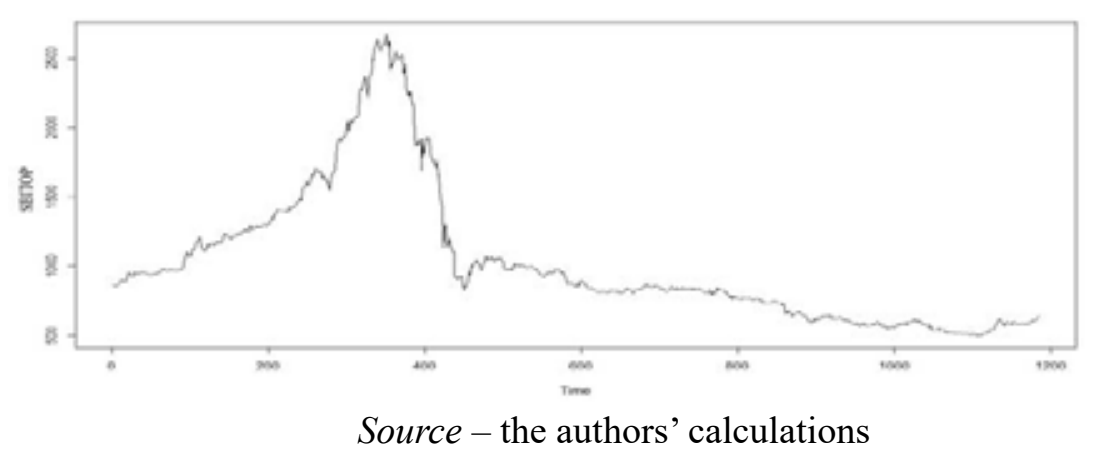


Figure 4.1. - SBITOP stationary time series (ARIMA time series $(3,1,1)$ of SBITOP)

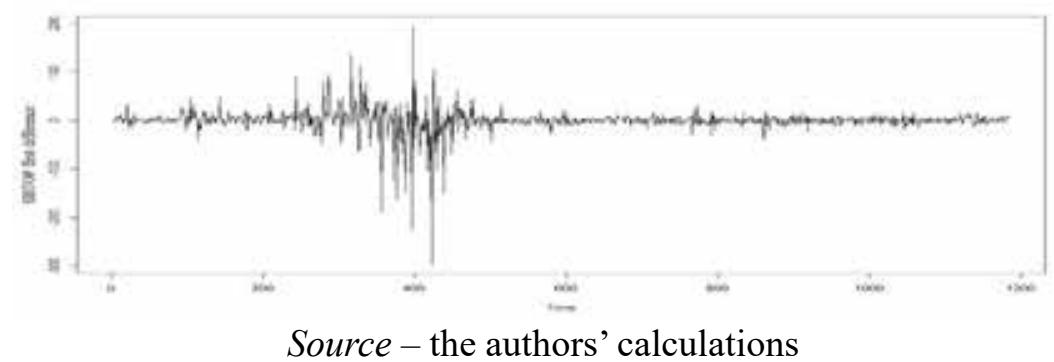

The Kwiatkowski-Phillips-Schmidt-Shin (KPSS) stationarity test (Kwiatkowski et al. 1992) is also performed and the ARIMA time series $(4,1,2)$ of SBITOP is derived.

Figure 5. - Non-stationary time series of SUNSPOTS

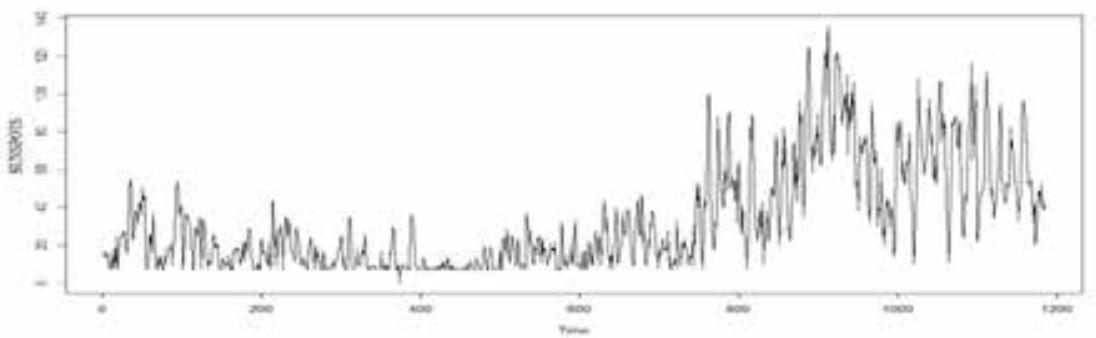

Source - the authors' calculations

Figure 5.1. - SUNSPOTS stationary time series (ARIMA time series $(4,1,2)$ of SUNSPOTS

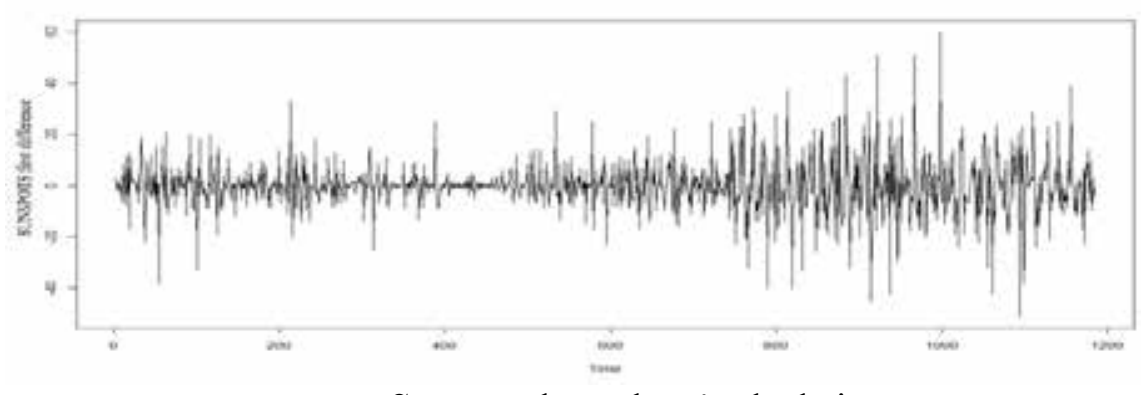

Source - the authors' calculations
Additional tests are performed in order to find other ARIMA models. The results are ARIMA $(1,0,1)$ with non-zero mean, and according to Phillips-Perron stationarity test, the time series ARIMA $(1,0,1)$ of SUNSPOTS with non-zero mean is derived.

Cointegration of time series is tested next (Table 6). It is a classic linear regression of stationary time series (Phillips et al, 1988). Table shows the cointegration of indices and sunspots, obtained by cointegration test results (Table 6)

Table 6. - Phillips-Ouliaris Cointegration Test

\begin{tabular}{|l|r|r|r|}
\hline Pairs & $\begin{array}{r}\text { Phillips-Ouliaris } \\
\text { demeaned }\end{array}$ & $\begin{array}{r}\text { Truncation lag } \\
\text { parameter }\end{array}$ & p-value \\
\hline BELEX15 and BUX & -9.43 & 11 & 0.15 \\
\hline BELEX15 and CROBEX & -33.37 & 11 & 0.01 \\
\hline BELEX15 and SBITOP & -14.32 & 11 & 0.15 \\
\hline $\begin{array}{l}\text { BELEX15 and } \\
\text { SUNSPOTS }\end{array}$ & -11.92 & 11 & 0.15 \\
\hline BUX and CROBEX & -17.05 & 11 & 0.10 \\
\hline BUX and SBITOP & -17.44 & 11 & 0.09 \\
\hline BUX and SUNSPOTS & -24.85 & 11 & 0.02 \\
\hline CROBEX and SBITOP & -18.27 & 11 & 0.08 \\
\hline $\begin{array}{l}\text { CROBEX and } \\
\text { SUNSPOTS }\end{array}$ & -12.09 & 11 & 0.15 \\
\hline SBITOP and SUNSPOTS & -18.86 & & 0.07 \\
\hline
\end{tabular}

Source - the authors' calculations

The results of Table 7 are based on Phillips-Ouliaris Cointegration Test (Phillips et al, 1990) (Table 6). Based on the values of $p<0.05$ (Table 6), the hypothesis that a pair of time series are not cointegrated is rejected.

Table 7. - Time series cointegration test applied to stock indices and sunspots

\begin{tabular}{|l|r|r|r|r|}
\hline & BUX & CROBEX & SBITOP & SUNSPOTS \\
\hline BELEX15 & NO & YES & NO & NO \\
\hline BUX & & NO & NO & YES \\
\hline CROBEX & & & NO & NO \\
\hline SBITOP & & & & NO \\
\hline
\end{tabular}

Source - the authors' calculations 
The test results and the analysis of critical values suggest that the hypothesis of cointegration of time series of stock market indices and sunspots is rejected. If cointegration had been confirmed, it would have indicated a causal link between these series. The lack of cointegration leads to the conclusion that research in this area should continue, presumably with the data modification and implementation of various econometric and statistical tests and models. Granger causality is also done. It showed with $\mathrm{p}$ $<0.05$ that there is causality between stock market indices and sunspots, but in this research only correlation results are presented further as a main focus of the research.

\section{RESULTS AND DISCUSSION}

From the table it can be observed that correlations are stronger for the data with no zero sunspots than in cases when the values of zero sunspots are taken into account.

Table 8. - The correlation between the stock indices and sunspots

\begin{tabular}{|c|c|r|r|r|r|}
\hline & Time period & $\begin{array}{c}\text { BELEX15- } \\
\text { SUNSPOTS }\end{array}$ & $\begin{array}{c}\text { BUX- } \\
\text { SUNSPOTS }\end{array}$ & $\begin{array}{c}\text { CROBEX- } \\
\text { SUNSPOTS }\end{array}$ & $\begin{array}{c}\text { SBITOP- } \\
\text { SUNSPOTS }\end{array}$ \\
\hline $\begin{array}{c}\text { All data } \\
\text { with } \\
\text { zero } \\
\text { sunspot } \\
\text { values }\end{array}$ & $2005-2012$ & $-0.397^{* *}$ & $-0.198^{* *}$ & $-0.394^{* *}$ & $-0.527^{* *}$ \\
\hline & 2005 & 0.139 & 0.053 & $-0.679^{* *}$ & $0.696^{* *}$ \\
\hline & 2006 & -0.027 & 0.078 & 0.038 & 0.031 \\
\hline & 2007 & $-0.224^{* *}$ & -0.106 & $-0.243^{* *}$ & $-0.280^{* *}$ \\
\hline & 2008 & 0.082 & 0.059 & 0.088 & 0.09 \\
\hline & 2009 & $0.264^{* *}$ & $0.314^{* *}$ & $0.240^{* *}$ & $0.154^{*}$ \\
\hline & 2010 & $-0.345^{* *}$ & -0.059 & $-0.323^{* *}$ & $-0.241^{* *}$ \\
\hline & 2011 & $-0.600^{* *}$ & $-0.622^{* *}$ & $-0.663^{* *}$ & $-0.633^{* *}$ \\
\hline $\begin{array}{c}\text { All data } \\
\text { without } \\
\text { zero }\end{array}$ & 2012 & $-0.243^{* *}$ & $-0.317^{* *}$ & $-0.165^{*}$ & $-0.164^{*}$ \\
\hline $\begin{array}{c}\text { sunspot } \\
\text { values }\end{array}$ & $205-2012$ & $-0.433^{* *}$ & $-0.414^{* *}$ & $-0.426^{* *}$ & $-0.537^{* *}$ \\
\hline & 2005 & $0.296^{*}$ & -0.161 & $-0.703^{* *}$ & $0.666^{* *}$ \\
\hline & 2006 & -0.005 & $0.235^{* *}$ & -0.054 & -0.024 \\
\hline
\end{tabular}

\begin{tabular}{|c|c|c|c|c|c|}
\hline & 2007 & $-0.191^{*}$ & -0.071 & -0.069 & -0.152 \\
\hline & 2008 & 0.189 & $0.242^{*}$ & 0.183 & 0.181 \\
\hline & 2009 & $0.352^{* *}$ & $0.498^{* *}$ & $0.345^{* *}$ & 0.199 \\
\hline & 2010 & $-0.225^{* *}$ & 0.106 & $-0.251^{* *}$ & $-0.225^{* *}$ \\
\hline & 2011 & $-0.603^{* *}$ & $-0.622^{* *}$ & $-0.663^{* *}$ & $-0.629^{* *}$ \\
\hline & 2012 & $-0.243^{* *}$ & $-0.317^{* *}$ & $-0.165^{*}$ & $-0.164^{*}$ \\
\hline $\begin{array}{l}\text { Log - } \\
\text { all data } \\
\text { with } \\
\text { zero }\end{array}$ & $2005-2012$ & $-0.422^{* *}$ & -0.034 & $-0.398^{* *}$ & $-0.627^{* *}$ \\
\hline & 2005 & 0.011 & 0.175 & $-0.589^{* *}$ & $0.648^{* *}$ \\
\hline & 2006 & -0.023 & -0.023 & 0.101 & 0.077 \\
\hline & 2007 & $-0.233^{* *}$ & -0.109 & $-0.279^{* *}$ & $-0.289^{* *}$ \\
\hline & 2008 & 0.074 & 0.044 & 0.084 & 0.091 \\
\hline & 2009 & $0.244^{* *}$ & $0.265^{* *}$ & $0.221^{* *}$ & $0.155^{*}$ \\
\hline & 2010 & $-0.376^{* *}$ & $-0.138^{*}$ & $-0.324^{* *}$ & $-0.222^{* *}$ \\
\hline & 2011 & $-0.583^{* *}$ & $-0.610^{* *}$ & $-0.650^{* *}$ & $-0.637^{* *}$ \\
\hline & 2012 & $-0.248^{* *}$ & $-0.306^{* *}$ & $-0.155^{*}$ & $-0.145^{*}$ \\
\hline $\begin{array}{c}\text { Log - } \\
\text { all data } \\
\text { without } \\
\text { zero }\end{array}$ & $2005-2012$ & $-0.539^{* *}$ & $-0.379^{* *}$ & $-0.487^{* *}$ & $-0.663^{* *}$ \\
\hline & 2005 & 0.032 & -0.102 & $-0.677^{* *}$ & $0.682^{* *}$ \\
\hline & 2006 & 0.048 & $0.207^{* *}$ & -0.016 & 0.006 \\
\hline & 2007 & $-0.218^{*}$ & -0.074 & -0.103 & -0.159 \\
\hline & 2008 & 0.065 & 0.074 & 0.070 & 0.066 \\
\hline & 2009 & $0.378^{* *}$ & $0.501^{* *}$ & $0.364^{* *}$ & $0.236^{*}$ \\
\hline & 2010 & $-0.226^{* *}$ & 0.118 & $-0.251^{* *}$ & $-0.234^{* *}$ \\
\hline & 2011 & $-0.592^{* *}$ & $-0.614^{* *}$ & $-0.653^{* *}$ & $-0.635^{* *}$ \\
\hline & 2012 & $-0.255^{* *}$ & $-0.299^{* *}$ & $-0.158^{*}$ & $-0.131^{*}$ \\
\hline $\begin{array}{c}\text { Returns } \\
\text { - all } \\
\text { data } \\
\text { with } \\
\text { zero }\end{array}$ & 2005-2012 & $0.068^{* *}$ & -0.009 & 0.040 & 0.046 \\
\hline
\end{tabular}




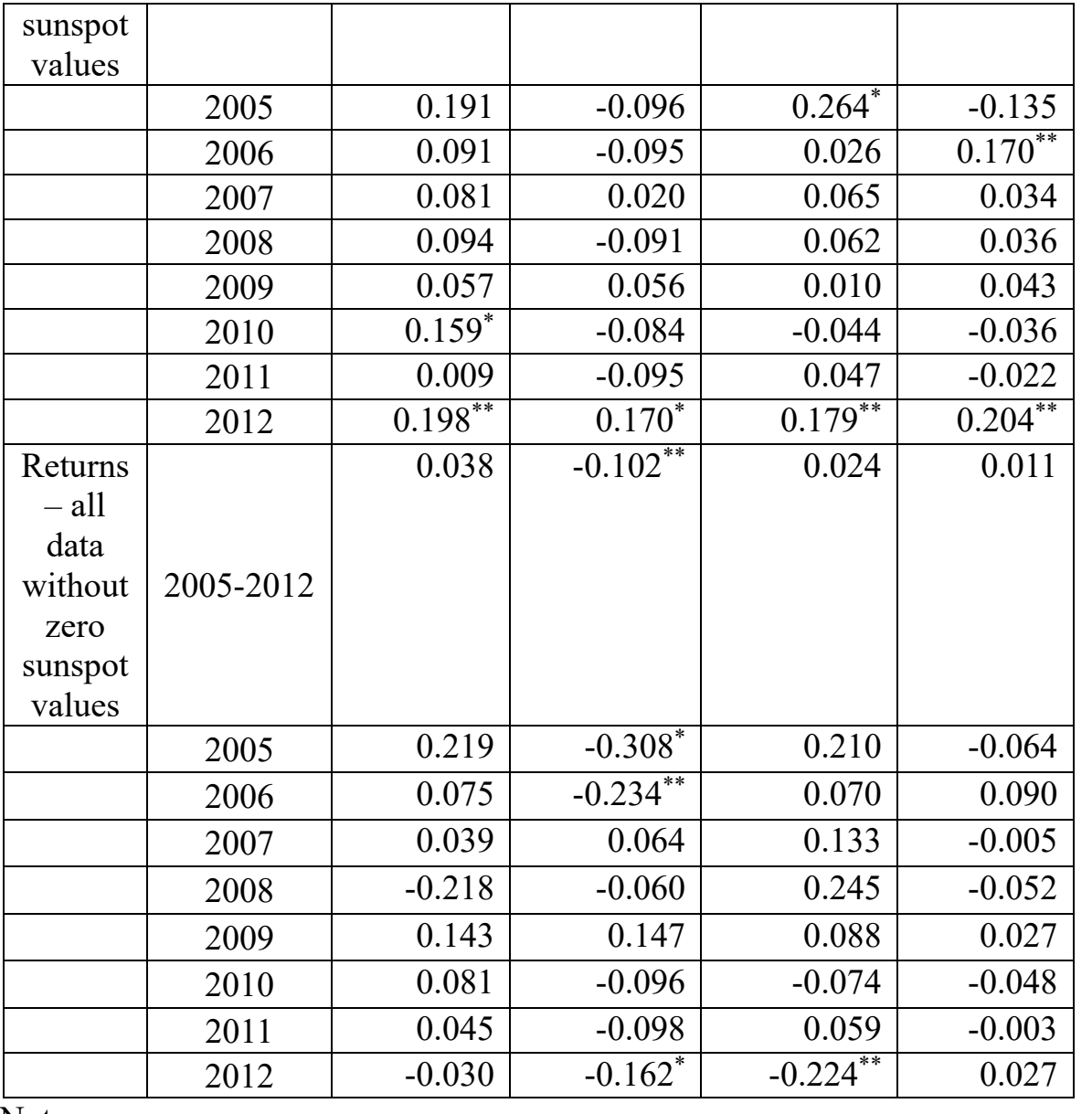

Note:

Correlation is significant at the 0.05 level

** Correlation is significant at the 0.01 level (2-tailed)

Source - the authors' calculations

Table 8 shows the correlations between the stock indices and sunspots when zero sunspot values are included, as well as when they are not. The analysis also includes the correlation testing when data transformations (logs, returns) are applied. The results indicate that sunspot and stock indices time series have a negative correlation. The correlation strength is increased if the days with no sunspot change are excluded (values without zero). The data analysis excluding zero sunspots is statistically validated, as well as the use of such data and their correlations. Negative correlation between sunspots and stock indices indicates the directions of sunspot and stock index changes. Namely, if the number of sunspots rises, stock index values decline. The correlation strengths for the whole study period (2005-2012; data without zero) move from -0.414 (BUXSUNSPOTS), -0.426 (CROBEX-SUNSPOTS), -0.433 (BELEX15SUNSPOTS) to -0.537 (SBITOP-SUNSPOTS). The closer to 1 the values are (in positive or negative sense), the stronger the correlation.

Graphic comparisons of the obtained stock index and sunspot correlations are also created by years (the period from 2005 to 2012; log data without zeros), in Fig. 6, 7, 8 and 9.

Figure 6. - Comparison of BELEX15 (logarithm Lg10 data), SUNSPOTS and their correlations by years, for the period 2005-2012

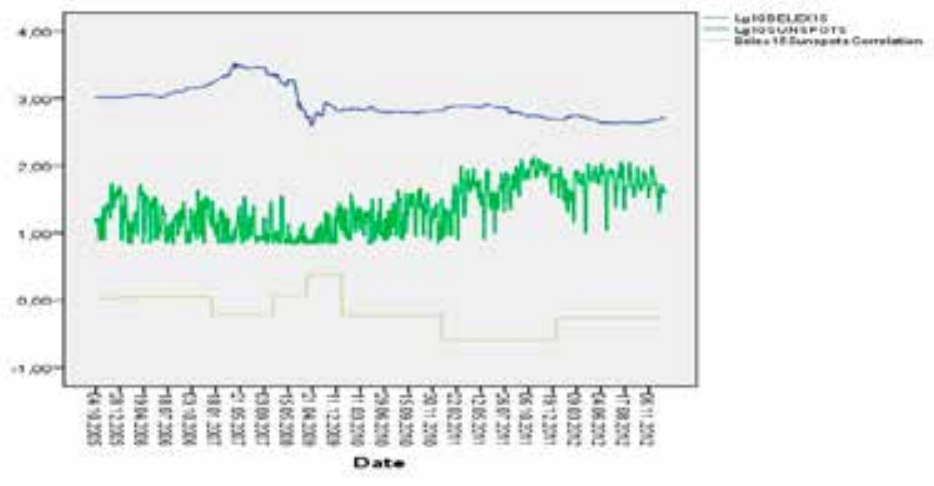

Source - the authors' calculations

Figure 7. - Comparison of BUX (logarithm Lg10 data), SUNSPOTS and their correlations by year, for the period 2005-2012
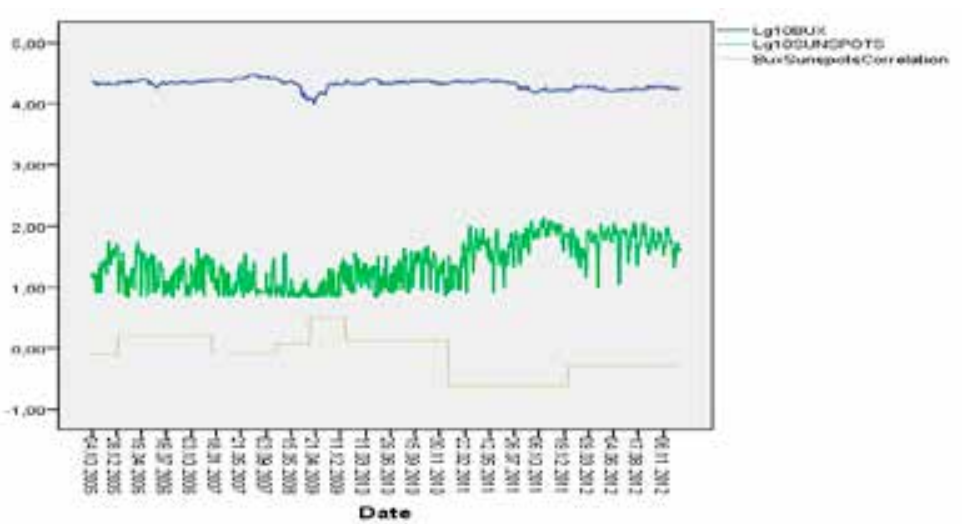

Source - the authors' calculation 
Figure 8. - Comparison of CROBEX (logarithm Lg10 data), SUNSPOTS and their correlations by year, for the period 2005-2012

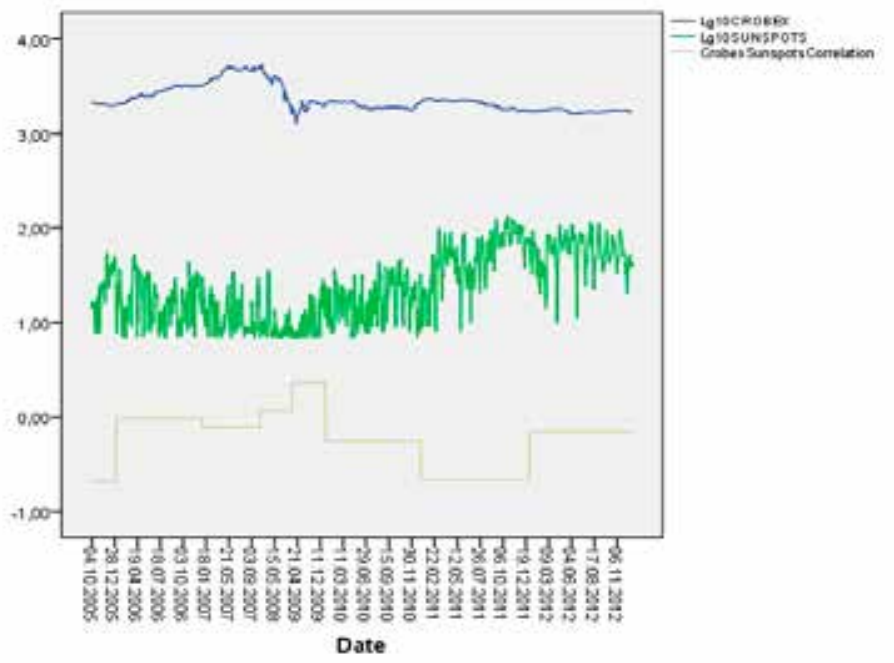

Source - the authors' calculations

Figure 9. - Comparison of SBITOP (logarithm Lg10 data), SUNSPOTS and their correlations by year, for the period 2005-2012

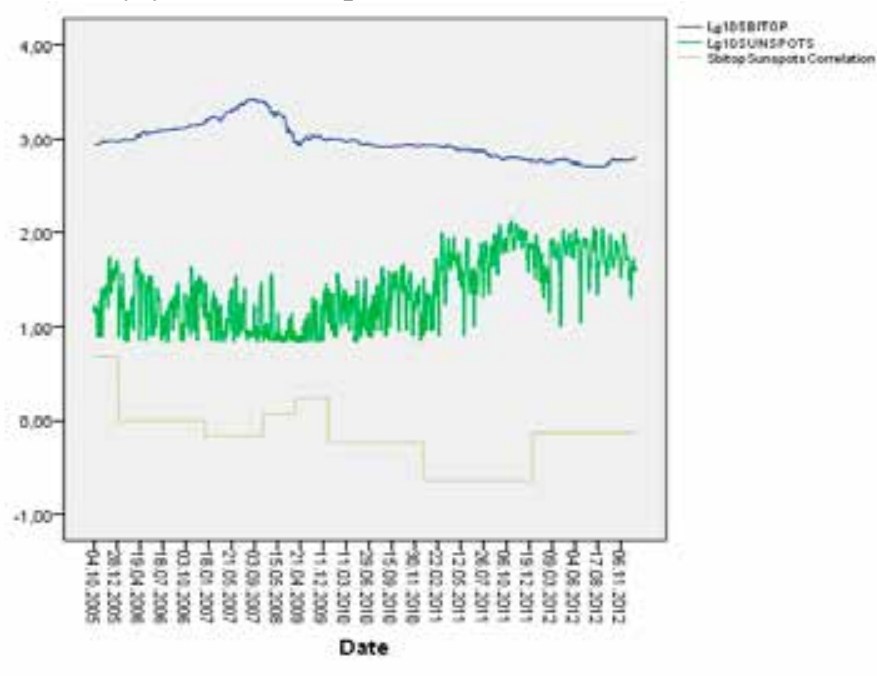

Source - the authors' calculations

These figures represent the correlation of indices and sunspots by year, and their movements. Stock index and sunspot data are transformed to logarithms because of technical reasons, in order to visualize monitored data better.

\section{CONCLUSIONS}

The analysis of time series using tests of stationarity and cointegration is a statistical discipline that records the most dynamic development in recent decades. Decision-making process is often associated with anticipation of future variable values whose changes depend on time, so modern econometric analysis of time series is widely used in financial analysis and business decision-making in conditions of risk and uncertain future.

In order to describe an event with its indications and consequences better, it is necessary to investigate the nature of the problem well, its properties and its behaviour. Distribution normality of the investigated time series is significant for conclusions about the nature of the studied economic phenomena and application of certain theoretical insights and models. Since the data are not normally distributed (which is in line with previous empirical studies), the subsequent analysis are intended to determine the precise nature of interrelationships and causal relationship of these variables. The results indicate a statistically significant negative correlation between the stock indices and sunspots. The negative correlation implies that an increased number of sunspots leads to reduced value of the stock indices and vice versa.

The research results confirm the defined hypothesis $\mathrm{H}_{1}$ that there is a statistically significant negative correlation between the indices of the observed four stock markets and sunspot activity, measured by their number, in the period 2005-2012.

The hypothesis $\mathrm{H}_{2}$ is rejected in the study, i.e. time series of the stock market indices are not cointegrated with the sunspot time series, which indicates the need for further research of the interdependence, combining other techniques, methods and models of modern quantitative financial analysis.

Stock index series are not stationary, they have a unit root and the series are random walks, thus confirming the hypothesis $\mathrm{H}_{3}$.

The hypothesis $\mathrm{H}_{4}$ is accepted in the study. Series of stock market indices have a normal distribution, which agrees with numerous studies and theoretical arguments in econophysics.

Having in mind obtained results of the research it is important to emphasize that statistically significant negative correlation between the indices of the observed four stock markets and sunspot activity exists, 
measured by their number, in the period 2005-2012, and that time series of the stock market indices are not cointegrated with the sunspot time series. These conclusions have significant both scientific and practical importance, especially as a basis for further researches in examined area.

Time series models examine the impact of historical values of a phenomenon on its current and future values. This approach enables the study of the phenomenon behaviour in time and gives good results, especially if a large number of historical data is available. The lack of a large number of data is one of the limitations of the research. It is the one of the causes not confirming the cointegration of sunspot time series with stock market index series. Research limitations are also the lack of liquidity and the market "shallowness" in the countries that have completed the transition process, lack of market efficiency and insufficiently effective financial institutions, high level of insider trading and systemic risk, as well as the significant impact of external shocks on the investment process and effectiveness.

Future research should include continuous monitoring of the stock market conditions and opportunities in transition countries, with special emphasis on possible prediction of their movement directions in accordance with sunspot changes and behavioural aspects of changes in prices and returns on stock markets, based on the behaviour and predictability of solar activity. Initial results, both in numerous studies and in this study, which is focused mainly on the transition countries, confirm such interdependence and encourage the continual research in this area in future, using regression analysis, more complex models and methods of econometrics and econophysics.

\section{САЖЕТАК}

\section{СУНЧЕВЕ ПЕГЕ И БЕРЗАНСКА ТРЖИШТА: ЕМПИРИЈСКИ}

\section{ДОКАЗИ МЕБУЗАВИСНОСТИ У ЗЕМЉАМА У ТРАНЗИЦИЈИ}

Еконофизика је нова и нарастајућа научна дисциплина која настоји да повеже и утврди међузависност између физичких појава и економске активности људи. Све је већи број радова који настоје да докажу емпиријску повезаност и узрочно-последичну међузависност између сунчевих пега и понашања берзанских индекса. Теоријски основ ове везе заснива се на чињеници да сунчеве пеге узрокују појачану геомагнетну активност Земље, а ова узрокује промене у психологији и понашању људи, доводећи до таласа оптимизма и песимизма, што утиче на интензитет инвестирања на берзанским тржиштима, цене акција и величину приноса. Стога, $\mathrm{y}$ раду се истражује емпиријска међузависност између активности сунчевих пега и понашања берзанских индекса на четири нарастајућа тржишта доскорашњих земаља у транзицији (Мађарска, Словенија, Хрватска и Србија). Анализиран је период од седам година (2005-2012.), јер коинцидира са временом избијања глобалне економске кризе (крај 2008. године) Резултати истраживања упућују на закључак да емпиријска међузависност и узрочност постоји, у складу са теоријским очекивањима.

Кључне речи: Сунчеве пеге, берзанска тржишта, земље у транзицији, корелација, коинтеграција.

\section{REFERENCES}

1. Collins, C.J., An inquiry into the effect of sunspot activity on the stock market, Financial Analysts Journal, 1965, pp. 45-56.

2. Dickey, D.A., Fuller, W.A., Distribution of the estimators for autoregressive time series with a unit root, Journal of the American Statistical Association, Vol. 74, No. 366, 1979, pp. 427-431.

3. Dimitrijevic, B., Djosevic, M., Relationship between economics and physics - econophysics as new scientific discipline and answer to the world economic crisis, Proceedings of the fourth science symposium with international involvement of Educons University at Sremska Kamenica, Sremska Kamenica - Novi Sad, May 29-30 2013, pp. 335361

4. Fuller, W.A. Introduction to Statistic Time Series, New York, Wiley, 1976.

5. Hampson, J., Sun spots solar activity and the financial markets part II, The Market Oracle, http://www.marketoracle.co.uk/Article27341.html (accessed 29 August 2013), 2011.

6. Hirshleifer, D., Shumway, T., Good day sunshine: Stock returns and the weather, The Journal of Finance, Vol. 58, Issue 3, 2003, pp. 1009-1032.

7. Hudson, R., Comparing security returns is harder than you think: Problems with logarithmic returns, Available at SSRN 1549328 academia.edu, 2010.

8. Johnson, B.D., The Sunspot Cycle, Quaternary Geology http://academic.emporia.edu/aberjame/student/johnson5/sunspotcycle.ht $\mathrm{ml}$ (accessed 22 July 2013), 2011.

9. Jovanovic, F., Schinckus, C., The history of econophysics' emergence: a new approach in modern financial theory, History of Political Economy, Vol. 45, Issue 3, 2013, pp. 443-474. 
10. Kamstra, M.J., Kramer, L.A., Levi, M.D., Winter blues: A SAD stock market cycle, The American Economic Review, Vol. 93, No. 1, 2003, pp. 324-343.

11. Krivelyova, A., Robotti, C., Playing the field: geomagnetic storms and the stock market, Working Paper, Federal Reserve Bank of Atlanta, 2003.

12. Kwiatkowski, D., Phillips, P.C.B., Schmidt, P., Shin, Y., Testing the null hypothesis of stationarity against the alternative of a unit root, Journal of Econometrics, Vol. 54, Issues 1-3, 1992, pp. 159-178.

13. Meucci, A., Quant nugget 2: Linear vs. compounded returns-Common pitfalls in portfolio management, GARP Risk Professional, 2010, pp. 4951.

14. Mladenovic, Z., Nojkovic, A., Analiza vremenskh serija: primeri iz srpske privrede, First Edition. Belgrade, Faculty of Economics, 2008.

15. Modis, T., Sunspots, GDP and the stock market, Technological Forecasting and Social Change, Vol. 74, Issue 8, 2007, pp. 1508-1514.

16. Phillips, P.C.B., Ouliaris, S., Testing for integration using principal component methods, Journal of Economic Dynamics and Control, Vol. 12, Issue 2, 1988, pp. 205-230.

17. Phillips, P.C.B., Ouliaris, S., Asymptotic properties of residual based tests for cointegration, Econometrica: Journal of the Econometric Society, Vol. 58, No. 1, 1990, pp. 165-193. 